\title{
OBSERVATIONS ON BREAK-UP IN THE MACKENZIE RIVER AND ITS DELTA IN I $954^{*}$
}

\author{
By R. J. E. Brown \\ (Research Officer, Permafrost Section, Division of Building Research, \\ National Research Council of Canada)
}

\begin{abstract}
Winter conditions on the Mackenzie River and Delta in North-west Canada are discussed. Daily observations during the break-up period of the Mackenzie River for 1954 are recorded, as well as a general record of the break-up of ice in the delta and detailed observations of the break-up in one of the main channels.

RÉsumÉ. L'article concerne les conditions climatologiques d'hiver au Nord-Ouest du Canada dans la région du fleuve Mackenzie et de son delta. On y relate les observations journalières effectuées pendant la période de dégel du Mackenzie en 1954, on y décrit également dans les grandes lignes la débâcle du delta et on y rapporte quelques observations détaillées sur le dégel de l'un des principaux chenaux.
\end{abstract}

\section{The Mackenzie River and Delta}

The Mackenzie River system ranks as one of the eight great river systems of the world (Fig. I, p. 135). On the North American continent it is exceeded in length and drainage area only by the Mississippi River ${ }^{1}$. The total area of its basin is approximately $\mathrm{I}, 760,000 \mathrm{~km} .{ }^{2}$ or somewhat more than one-fifth of the area of Canada including some of the largest freshwater lakes in the world. Although over $255^{\circ} \mathrm{km}$. in length from Waterways, Alberta, to the Arctic Coast, the entire waterway is navigable except for a series of rapids on the Slave River between Fort Fitzgerald and Fort Smith.

The Mackenzie Delta is a maze of meandering channels and small stagnant lakes covering an area of more than $\mathrm{I}_{3}, 000 \mathrm{~km}^{2}$ (Fig. 2, p. I35). The delta begins near Point Separation, where the river divides into three main channels: the Middle Channel averaging $2.4 \mathrm{~km}$. in width; the East Channel, approximately $150 \mathrm{~m}$. wide down to Reindeer Depot and then widening to over $0.8 \mathrm{~km}$.; and the Peel Channel with an average width of approximately $\mathrm{I} 50 \mathrm{~m}$. which becomes the West Channel with an average approximate width of $0.8 \mathrm{~km}$. Between these main channels are thousands of interconnecting streams varying in width from $100 \mathrm{~m}$. to only a few metres.

FREEZE-UP AND BREAK-UP

The river and its delta are icebound nearly eight months of the year. During this period, all supplies for river settlements must be brought in by aircraft.

Freeze-up and break-up each last approximately six weeks and are important periods especially to those in the delta where there are no landing strips and the only communication is by float- and ski-equipped aircraft. During these transition periods, therefore, settlements in the delta are completely isolated.

The break-up period lasts from the first melting of the snow on the ice to the clearing of ice in the river and delta. The significant period for aircraft is when the ice is unsafe for ski-equipped aircraft and there is not sufficient open water for float-equipped aircraft to operate. The time the main body of river ice first breaks is sometimes given as the time of break-up although often it is still quite solid and may remain several days before moving downstream.

\section{Winter Conditions}

\section{Fanuary Air Temperatures on the River}

The Mackenzie waterway extends through $16^{\circ}$ of latitude, and therefore there is a marked gradation in the temperature regime from south to north ${ }^{2}$.

* This paper is a contribution from the Division of Building Research. National Research Council of Canada and is published with the approval of the Director. 
The mean January daily temperature grades from $-23^{\circ} \mathrm{C}$. at Waterways to $-29^{\circ} \mathrm{C}$. at Fort Norman. In the vicinity of Fort Good Hope it is approximately $-32^{\circ}$ C. ; and in the delta, approximately $-29^{\circ} \mathrm{C}$. From Waterways to Norman Wells, the mean January daily minimum temperature ranges from $-29^{\circ} \mathrm{C}$. to $-34^{\circ} \mathrm{C}$. The gradation in mean January daily maximum temperature ranges from $-18^{\circ} \mathrm{C}$. at Waterways to $-23^{\circ} \mathrm{C}$. at Fort Simpson. From Fort Simpson to the Arctic Coast it is fairly constant at approximately $-24^{\circ} \mathrm{C}$.

\section{Winter Air Temperatures in the Delta}

The delta, $320 \mathrm{~km}$. north of the Arctic Circle, receives no sunlight from the end of November until the middle of January.

The maximum air temperature recorded at Aklavik remained below $0^{\circ} \mathrm{C}$. from ${ }_{1} 3$ October I953 to 2 May 1954 except for two short periods at the end of March when it rose to I. $7^{\circ} \mathrm{C}$. and $2 \cdot 8^{\circ} \mathrm{C}$. (Fig. 3, p. 137). Several very cold days occurred at the beginning of January 1954 with a low of $-50^{\circ} \mathrm{C}$. recorded on 5 January. Throughout the winter the average mean daily temperature was approximately $-25^{\circ} \mathrm{C}$.

\section{Conditions in the Delta Channels}

By the end of the winter, ice in the channels is generally more than $\mathrm{I} \mathrm{m}$. thick, overlain by snow varying in depth from a few centimetres to several metres. The ice is strong enough to support snowmobiles and other vehicles although areas of thin ice sometimes occur at the junctions of channels.

The following data, taken ${ }_{5}$ April 1954 on the Husky Channel $3 \mathrm{~km}$. upstream from its junction with the Peel Channel (Fig. 2), might be considered typical for the channels in the delta ; $23 \mathrm{~cm}$. of snow covered the ice in the middle of the channel (snow cover consisted of $2.5 \mathrm{~cm}$. of powder snow over $20.5 \mathrm{~cm}$. of crystallized ice particles); ice in the channel had attained its maximum thickness, approximately $\mathrm{I} \cdot 22 \mathrm{~m}$.; the water, at its lowest level, measured $5.54 \mathrm{~m}$. near the middle of the channel and was clear, with no evidence of current.

\section{BREAK-UP OF THE MACKENZIE River}

The break-up begins at the source and progresses northward downstream. The ice near the mouth, which moves out last, forms a barrier and causes severe ice jams and floods.

Break-up starts at Great Slave Lake and progresses slowly, usually reaching each settlement at about the same time each year. In 1954 break-up occurred a week later than usual because air temperatures were below average during April and May. The Liard River, which empties into the Mackenzie River at Fort Simpson, usually breaks before the Mackenzie. The Mackenzie, between Great Slave Lake and Fort Simpson, breaks and clears of ice several weeks before the ice in Great Slave Lake.

In 1954 observations on the break-up of the Mackenzie River were taken in connexion with an extensive survey of the whole delta for the relocation of the northern settlement of Aklavik. Detailed knowledge of the break-up of the river was needed in connexion with the design of the necessary transportation facilities at the proposed new site for Aklavik.

Daily observations of break-up were made by the Royal Canadian Corps of Signals in the settlements on the Mackenzie River (Table I). Wireless reports from the signal stations recorded the following observations: 


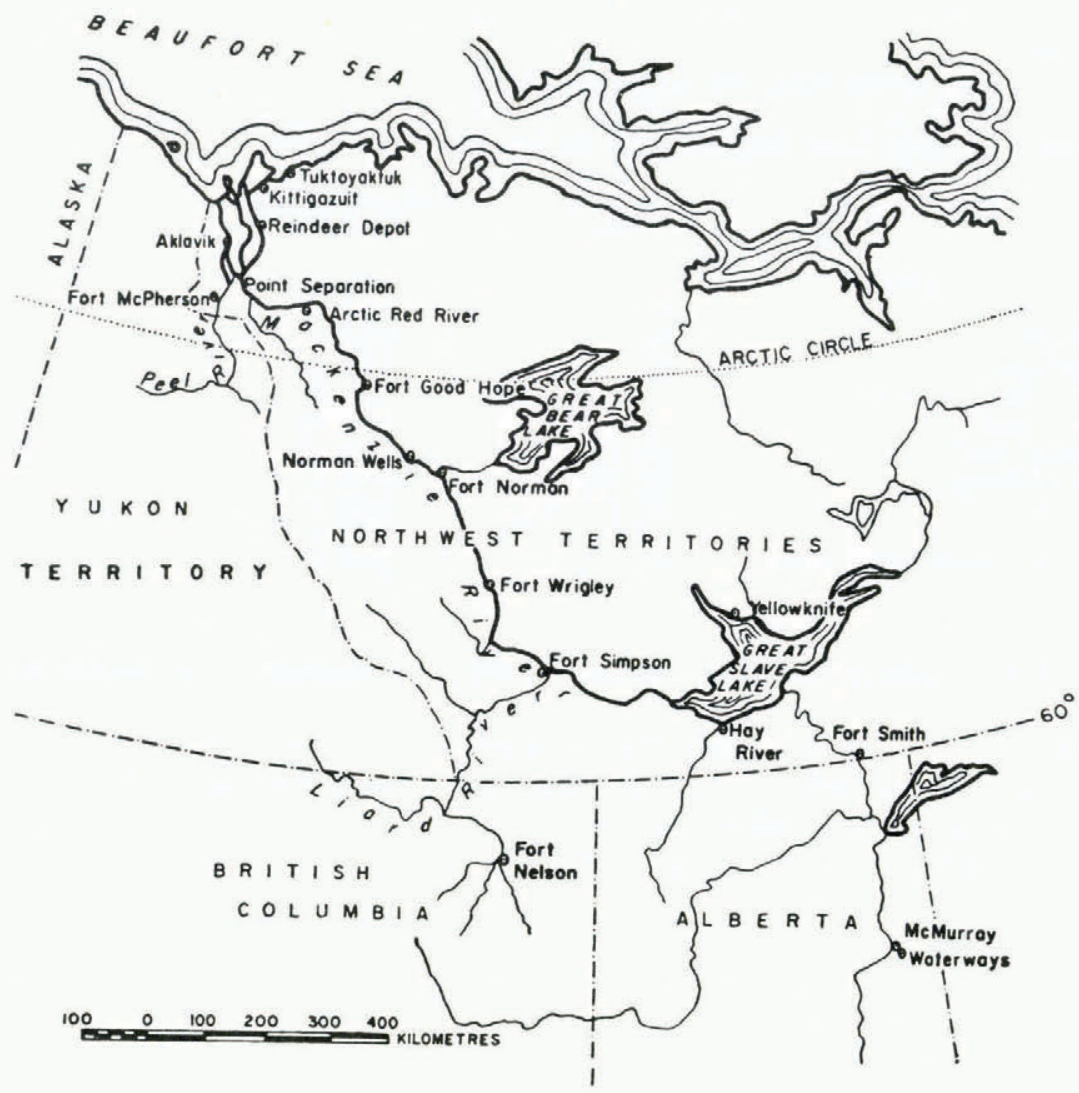

Fig. I. The Mackenzie Waterway

Fig. 2. The Mackenzie River Delta

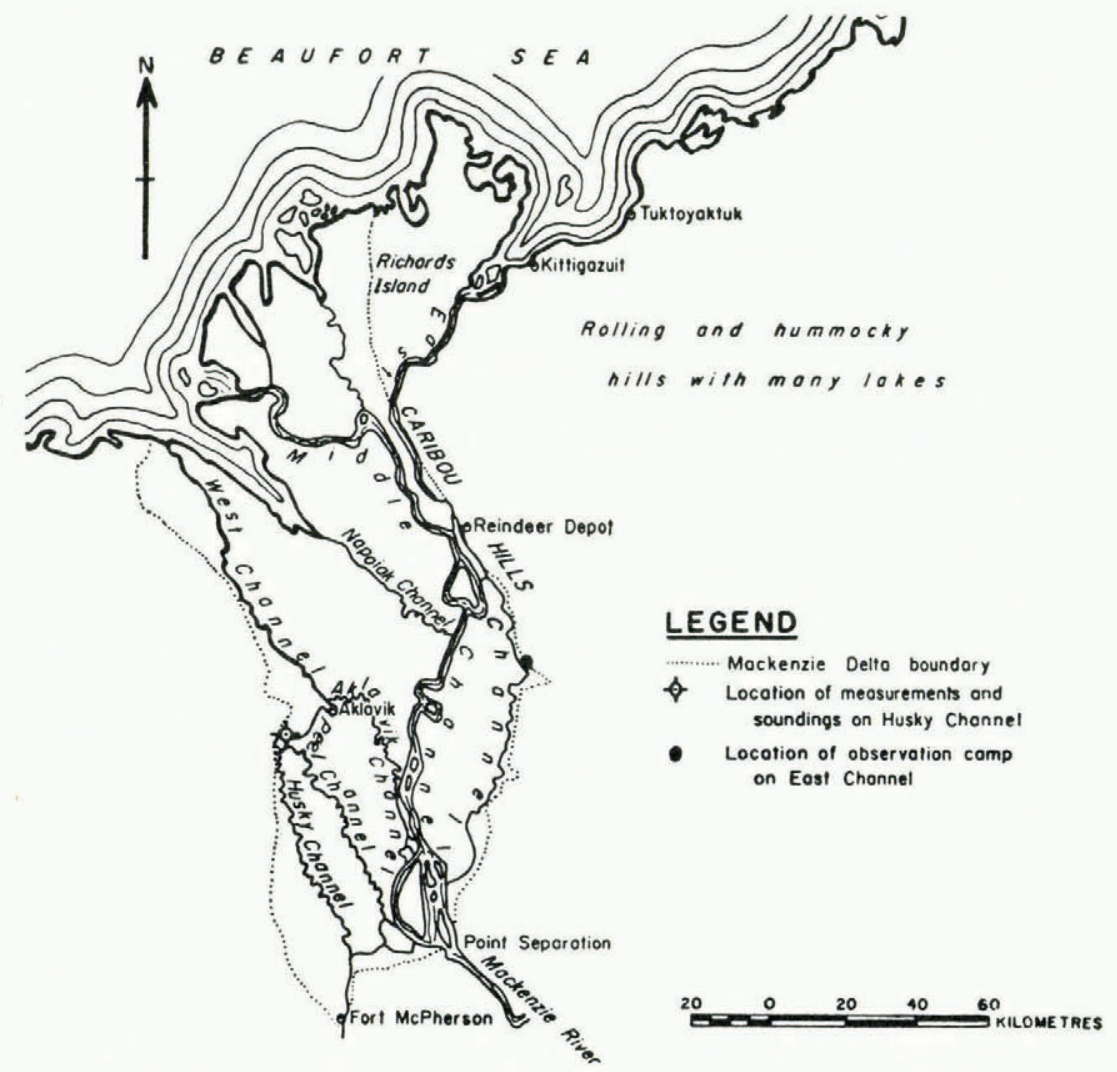




\section{Table I. 1954 Break-uP : Mackenzie River and Delta Stations}

$\begin{array}{lcc}\text { Station } & \begin{array}{c}\text { Latitude of } \\ \text { Station }\end{array} & \begin{array}{c}\text { Approximate Date } \\ \text { of Break-up }\end{array} \\ \begin{array}{l}\text { Liard River (near mouth) } \\ \text { Fort Simpson }\end{array} & 62^{\circ} & \text { May 14 } \\ \text { Fort Wrigley } & 63^{\circ} & \text { May 19 } \\ \text { Fort Norman } & 65^{\circ} & \text { May 20 } \\ \text { Bear River (near mouth) } & 65^{\circ} & \text { May 21 } \\ \text { Norman Wells } & 66^{\circ} 30^{\prime} & \text { May 28 } \\ \text { Fort Good Hope } & 67^{\circ} 30^{\prime} & \text { May 24 } \\ \text { Arctic Red River } & \text { May 22 } \\ \text { Fort McPherson } & 67^{\circ} 30^{\prime} & \text { June 1 } \\ \text { Aklavik } & 69^{\circ} & \text { May 25 } \\ \text { East Channel (observation post) } & 69^{\circ} & \text { June 5 } \\ & & \text { May 29 }\end{array}$

I9 May

Fort Simpson. Liard River broke 14 May and is almost free of ice. Mackenzie River, upstream, unbroken.

Fort Wrigley. Ice rose $\mathrm{I} \cdot 5 \mathrm{~m}$. and is still rising. Water running free on both sides.

Fort Norman. Shore leads on both sides $30 \mathrm{~m}$. wide, with water rising at normal rate, but main body solid. Break-up 5 or 6 days behind normal.

Norman Wells. Ice holding but becoming soggy on top.

20 May

Fort Wrigley. Main ice body broke and moved $180 \mathrm{~m}$. Water level has risen $2.4 \mathrm{~m}$. and small ice pans are moving in the shore leads.

Fort Norman. Water level rising $2.5 \mathrm{~cm}$./hr.

2 I May

Fort Wrigley. Small pans moving in the shore leads. Water level dropped $25 \mathrm{~cm}$. in afternoon.

Fort Norman. Main ice body broke in morning with water level slightly above normal. Ice moved for a few hours, then stopped. Bear River still solid.

\section{May}

Fort Wrigley. Main ice body moved $\mathrm{I} 35 \mathrm{~m}$. at $22.00 \mathrm{hr}$.

Fort Norman. Water level rising slowly. Large opening in ice at mouth of Bear River but ice solid in that river.

Fort Good Hope. Ice body broke in afternoon and moved I mile.

Arctic Red River. Water level rising slowly.

Fort McPherson. Water level high but current slow.

23 May

Fort Norman. Ice moved for first time since 2 $\mathrm{I}$ May and water level began rising again.

Norman Wells. Main ice body broke at $07.35 \mathrm{hr}$.

24 May

Fort Wrigley. Main ice body broken up into quickly moving pans.

Norman Wells. Main ice body breaking into quickly moving pans.

25 May

Fort McPherson. Main ice body broke at $21.00 \mathrm{hr}$. and jammed at $22.30 \mathrm{hr}$. Water level rising very slowly. 

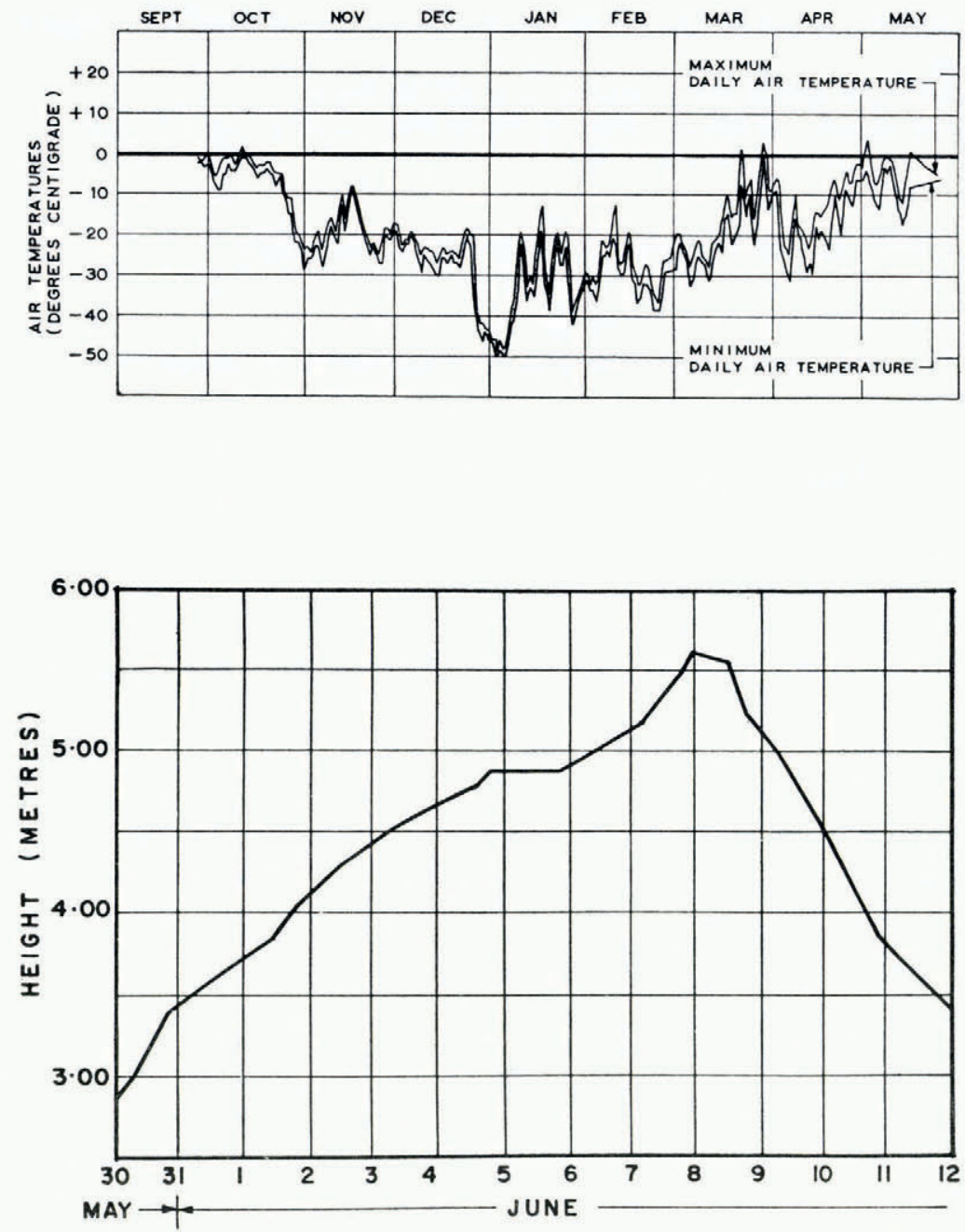

Fig. 3. Air temperatures at Aklavik, N.W.T., during the winter of I953-I954
Fig. 4. Water levels on East Channel of Mackenzie Delta at East Three, measured from low water level of winter 1953-1954 (Firstreading taken on 30 May when water level was $2.90 \mathrm{~m}$. above low water level)

\section{May}

Fort Norman. Ice pans thinning out as water levei rises to a record high.

Norman Wells. Ice pans moving quickly; water level very high.

Fort Good Hope. Ice clear from below Ramparts; current fast.

Arctic Red River. Main ice body still holding; water level rising quickly.

\section{May}

Fort Norman. Only a small amount of drift ice remains. Water level has dropped $\mathrm{I} \mathrm{m}$. since 26 May.

Norman Wells. River open except for some small pans. Water level high.

Fort McPherson. Ice moved a short distance in afternoon. 
28 May

Fort Norman. Few ice pans remain. River now open for navigation. Water level has dropped $25 \mathrm{~cm}$. since 27 May.

Norman Wells. River clear of ice except for pieces breaking off the shore.

Arctic Red River. No change in ice conditions since 27 May. Water level rising $2 \cdot 5 \mathrm{~cm}$. $/ \mathrm{hr}$.

29 May

Fort Norman. Mackenzie River clear of ice. River ice body broke during night. 3० May

Fort Good Hope. Ice pans running fast. Ice jammed $30 \mathrm{~m}$. high at mouth of Ramparts.

\section{I fune}

Arctic Red River. Main ice body broke at $13.00 \mathrm{hr}$.

\section{2 fune}

Arctic Red River. River almost clear of ice.

By 2 June, the ice had cleared from the Mackenzie River although ice pans were coming in from many tributaries.

\section{Break-up in the Delta of the Mackenzie River}

The first evidence of break-up is the melting of snow on the ice near the shore. This begins early in May when the air temperature rises above $0^{\circ} \mathrm{C}$. during the day. Melting snow from the mountains causes the river to rise in flood and as the water level rises, the ice in the channels is bowed up in the centre and held at the sides by the anchor ice. As the water continues to rise it breaks through in places, submerging the anchor ice which still holds firm under the water. Eventually the anchor ice breaks under increasing pressure and floats to the surface in the form of small pans. These are carried downstream in the shore leads leaving a continuous band of ice in the centres of the channels (Fig. 5, p. I4I).

Toward the end of May, the main body of ice in the channels breaks into large pans (Fig. 6, p. I4I). As the snow melts, the solid transparent ice changes to candle or honeycomb ice composed of long crystals oriented normal to the surface. Spaces between crystals are usually filled with water and the ice appears dark.

As the water level rises and the current increases, the ice cakes are ground against one another and the shore. Sharp bends in the channels cause jams and the ice may pile up for several kilometres. Just below Point Separation, several large islands hinder ice movements down the Middle and East Channels. In 1954, ice was funnelled into the Peel Channel and the west side of the delta several days before it moved into the Middle and East Channels. Jams often pile up on shore to a height of several metres, occasionally damaging trapper's cabins and pushing over small trees.

The water level reaches its peak at this time and then begins to recede. Within a few days the main body of ice, now broken and candled, moves downstream.

The end of the ice is marked by an accumulation of driftwood and other debris which has been picked up by the flood water. Eventually it is either stranded on the banks of channels or carried out to the open sea. Cakes of ice, covered with silt and stranded on shore, have been seen in July.

Early in June 1954, random observations were made by helicopter over various parts of the delta. During this period the water level reached the highest mark and the main ice bodies in the channels broke up and moved downstream. 
2 fune

Low islands in the Middle Channel submerged and heavy ice running; channel jammed with pans at mouth of Aklavik Channel. Aklavik Channel open $8 \mathrm{~km}$. down from its junction with the Middle Channel but ice not moving below this.

On Peel Channel, ice solid at Alkavik but broken up-stream above mouth of Husky Channel. Broken ice and driftwood formed jam at mouth of Phillip's Channel. Indian village at mouth of Peel Channel surrounded by water.

Ice on East Channel at junction with Middle Channel jammed solidly; ice had risen to top of bank, $6 \mathrm{~m}$. above winter low water level; here highest flood level since 1938 reached at midnight I June.

\section{3 fune}

Ice jammed in Middle Channel at Point Separation. Aklavik Channel plugged with broken cakes of ice near junction with Middle Channel (Fig. 7, p. I4I).

On Peel Channel at Aklavik large pans moving in shore lead; Government dock under water; current about $8 \mathrm{~km}$./hr. Up-stream heavy ice running at many points and some pans going into tributary channels. At Indian village, water level dropped nearly $1 \mathrm{~m}$. although further down-stream, rises in water level up to $\mathrm{I}_{5} \mathrm{~cm}$. reported in a period of $6 \mathrm{hr}$. In contrast to west side of delta, ice in East Channel and tributaries had not moved since I June.

\section{4 fune}

Ice conditions same as 3 June in Middle and Aklavik Channels. River ice broken but holding fast with occasional open stretches.

On Peel Channel, heavy ice at mouth of Husky Channel; up-stream channel relatively clear. Main ice body still solid at Aklavik and down-stream. Heavy concentration in East Channel below junction with Middle Channel.

\section{Fune}

Ice in Middle Channel moving rapidly as more pans arriving from Mackenzie River. Ice pans moving rapidly in Aklavik Channel and water level dropping. At midnight, 5 June, broken ice pans at Aklavik moved and by afternoon channel clear for $16 \mathrm{~km}$. down-stream (Fig. 8, p. $\mathrm{r}_{4} \mathrm{I}$ ).

West Channel and Napoiak Channel beginning to break up and clear of ice.

\section{Fune}

At midnight water level at maximum of $5.64 \mathrm{~m}$. above winter low level in East Channel at new site of Aklavik, $96 \mathrm{~km}$. by water down-stream from junction of East and Middle Channels.

By 9 June, delta channels were clear of ice except for a few small pans. Ice in the lakes was melting quickly and by the third week of June the lakes were practically free of ice.

\section{Break-up Observations on East Channel, i 954}

During the Aklavik Relocation Survey, the author established a camp on the east bank of the East Channel to observe break-up (Fig. 2). For a distance of about $60 \mathrm{~m}$. the shore protrudes slightly into the channel, forming a partial obstruction to the moving ice. On 23 April 1954, a benchmark was erected here from which the winter low water level and subsequent flood water levels were read from 29 May to in June. Ice conditions and water level were recorded at least twice daily and whenever a change occurred in the former (Fig. 4, p. 137). 
By 29 May, the anchor ice connecting the main ice body to the banks had broken up leaving continuous shore leads about $6 \mathrm{~m}$. wide on both sides of the channel. The main body of the ice had candled at the edges and short cracks extended into it. Day by day more cracks appeared in the main ice body and the snow on the surface slowly melted. Gradually the main body broke into large pans and the whole mass shifted back and forth from one bank to the other. The ice was mostly jammed up against the west shore of the East Channel leaving an open lead up to $30 \mathrm{~m}$. wide along the east bank. Periodically, pans up to $100 \mathrm{~m}$. in length and small strings of ice drifted down-stream in the shore leads (Fig. 9, p. 141).

The main ice body first moved on I June for a distance of $\mathrm{I} 80 \mathrm{~m}$. From then until 8 June, when the ice finally moved out, the main body advanced about $0.8 \mathrm{~km}$. down-stream. During this time the water rose at the rate of about $25 \mathrm{~cm}$. per day and reached the peak of $5.64 \mathrm{~m}$. above the winter low level on 8 June.

On 5 June, the channel was plugged with ice from bank to bank. Ice blocks were pushed up on shore to a height of $2.1 \mathrm{~m}$. at the up-stream end of the protruding bank and some soil was gouged out of the bank. The remainder of this beach was not affected by the moving ice.

On 9 June, four days after the Peel Channel cleared at Aklavik, the main ice body, now broken into pans, began to move and by the end of the day the channel was clear except for an occasional small pan and floating driftwood (Fig. Io, p. I4r).

\section{Conclusion}

The data presented do not necessarily pertain to average break-up conditions. Systematic observations over a period of years at many points would be necessary to establish the yearly trend of break-up ${ }^{3}$. It is known that break-up was abnormally late in 1954, perhaps because of the belowaverage cold weather in April and early May. Abnormally high temperatures in late May and early June, however, may have accelerated the break-up because the river and delta channels were cleared of ice at almost the normal time.

MS. received 20 September $195^{6}$

\section{RE F E R E N C E S}

I. Camsell, C., and Wyatt, M. The Mackenzie River Basin. (Revised edition.) Geological Survey, Department of Mines,

Memoir ro8, 1921.
2. Thomas, M. K. Climatological atlas of Canada. (Meteorological Division, Department of Transport, and Division of Building Research, National Research Council.) Ottawa, 1953. NRC No. 3151.

3. Williams, J. R. Observations of freeze-up and break-up of the Yukon River at Beaver, Alaska. Fournal of Glaciology, Vol. 2, No. 17 , 1955, p. 488-95.

Fig. 5 (top left). Looking north-east over West Channel north of Aklavik on 4 fune I954. Anchor ice has broken and floated down-stream leaving continuous band of ice in centres of channels.

Fig. 6 (top right). Looking east over junction of West Channel and first large channel north of Aklavik on 4 June 1954. Main ice body has broken into large pans

Fig. 7 (centre left). Middle Channel on 4 fune 1954. The ice has broken into small pans and formed a temporary jam Fig. 8 (centre right). Aerial view of Aklavik on Peel Channel on 5 fune 1954. Small pans and other debris mark end
of ice. Water has reached highest level

Fig. 9 (bottom left). Observation camp on East Channel at 23.05 hr., 3 Fune I954. Large pans from centre body fill shore lead. About 25 per cent of snow cover has melted off ice surface

Fig. Io (bottom right). Observation camp on East Channel at I8.I5 hr., 9 fune I954. Main ice body broken into small pans and moving rapidly. Channel clear of ice here $24 \mathrm{hr}$. later 
